\title{
Assessment of heavy metal pollution in sediments and their bioaccumulation in Phragmites australis frome Nil river (Jijel- Algeria)
}

\author{
Amira W. ${ }^{1,2, *}$ and Leghouchi E. ${ }^{2}$ \\ ${ }^{1}$ Département des Sciences Biologiques de l'Environnement, Faculté des Sciences de la Nature et de la Vie, Université de Bejaia, 06000 \\ Bejaia, Algérie \\ 2Laboratoire Biotechnologie, Environnement et Santé, Université de Jijel, 18000 Jijel, Algérie \\ Received: 16/10/2017, Accepted: 15/12/2017, Available online: 04/05/2018 \\ *to whom all correspondence should be addressed: e-mail: amira.widad@yahoo.fr
}

\section{Abstract}

The content of heavy metals in sediment and the aquatic plant Phragmites australis (roots and leaves), collected from six different stations along the Nil river, were determined providing information about heavy metals pollution status of this aquatic ecosystem.

The results showed that the abundance of heavy metals measured in the sediments decreased in the order: $\mathrm{Fe}>\mathrm{Zn}>\mathrm{Pb}>\mathrm{Cr}>\mathrm{Cd}$. Apart from $\mathrm{Cr}$ and $\mathrm{Fe}$, the concentration of heavy metals exceeded the background values. Metals concentrations were found decreasing with the increasing distance from the river mouth, suggesting that anthropogenic inputs, related to agricultural and domestic discharge into the river, are the major sources of heavy metals in the river sediments and aquatic plants.

The assessment of heavy metals pollution was carried out using geoaccumulation index (Igeo) and enrichment factor (EF). According to the mean values of Igeo, the sediment of Nil river is considered as moderately polluted with $\mathrm{Pb}$ and $\mathrm{Cd}$, unpolluted to moderately polluted with $\mathrm{Zn}$ and unpolluted with $\mathrm{Cr}$ and $\mathrm{Fe}$. The mean values of enrichment factor indicate that all stations presented moderate enrichment with $\mathrm{Zn}$, minor enrichment with $\mathrm{Cr}$ and moderately to severe enrichment with $\mathrm{pb}$ and $\mathrm{Cd}$ in three stations.

Regarding the plant samples, the results showed that the concentration of the elements analyzed in Phragmites australis did not exceed the threshold of phytotoxicity.

Mean concentrations of all elements were less in the plants organs compared to the concentrations of the same elements in the corresponding sediment sample. Metals accumulated by $P$. australis were mostly distributed in root tissues, as shown by the values of translocation factors (TF) which were $<1$. A positive association between the metal concentrations in $P$. australis organs and its environment was also found; this suggests that this plant can be used as biological indicator in biomonitoring studies.
Keywords: Nil river, Heavy metals, Sediments, Pollution, Phragmites australis.

\section{Introduction}

Heavy metals in aquatic ecosystems are considered as serious pollutants due to their environmental persistence, toxicity and ability to be incorporated into food chains (Banerjee et al., 2012). They enter these aquatic systems mainly through natural inputs such as weathering and erosion of rocks and anthropogenic sources including urban, industrial and agricultural activities, terrestrial runoff and sewage disposal (Barakat et al., 2012).

Once released in aquatic environments, heavy metals are generally bound to particulate matter, which eventually settle down and become incorporated into sediments. Therefore, surface sediments are the most important reservoir or sink of metals and other pollutants in aquatic environments (Boudet et al., 2011).

In the sediments, metals accumulate through complex physical and chemical adsorption mechanisms depending on the nature of the sediment matrix and the properties of the adsorbed compounds (Çevik et al., 2009). Moreover, accumulation or release of metals in sediments is largely controlled by their geochemistry, in particular, type and quantities of organic matter, grain size and cation exchange capacity (Naji et al., 2011).

Generally, it has been recognized that natural aquatic sediments absorb persistent and toxic chemicals to levels many times higher than the water column concentration (Milenkovic et al., 2005; Banerjee et al., 2012).

The increasing load of heavy metals cause imbalance in aquatic ecosystems and the biota growing under such habitats accumulate high amounts of heavy metals ( $\mathrm{Cu}, \mathrm{Zn}$, $\mathrm{Cd}, \mathrm{Cr}, \mathrm{Ni}$, etc.) which in turn, are being assimilated and transferred within food chains by the process of magnification (Kuntal et al., 2014).

Knowing the mechanism of accumulation, distribution and metabolism of metals in aquatic macrophytes is of great ecological, scientific and practical importance. From the 
environmental point of view, the importance is reflected in the fact that aquatic macrophytes could be used as biological indicators of pollution (Štrbac et al., 2014). Due to its ability to accumulate metals, availability throughout the year and large biomass, Phragmites australis (common reed) is suitable for biomonitoring studies for the evaluation of load levels of trace metals in aqueous ecosystems. The heavy metals concentration in $P$. australis tissues can be several ten to several thousand times higher than those in the surrounding water (Kastratović et al., 2013).

In this study the objectives were; to determine the distribution and concentration of trace metals in surface sediments and $P$. australis; to identify the quality assessment of surface sediments using geo-accumulation index (Igeo) and enrichment factor (EF) and to evaluate mobility according to the translocation factors (TF) and bioconcentration factors (BCF) for leaf and root in $P$. australis.

\section{Materials and methods}

\subsection{Study area}

The study area (Nil river) is located in Jijel, North East of Algeria, between Latitude: $36^{\circ} 49^{\prime} 40.04^{\prime \prime} \mathrm{N}$ and longitude $5^{\circ} 56^{\prime} 14.32^{\prime \prime} \mathrm{E}$. The Nil river springs in the mountains of Chahna and flows into the mediterranean sea. It has an approximate distance of $20 \mathrm{~km}$ and catchment area of about $303 \mathrm{~km}^{2}$. Boukaraa, Saayoud and Tassift are its major tributaries.

The river receives domestic wastewaters from the adjoining communities (Taher, Chekfa, Bazoul, Jimar) and runoff from agricultural land in its drainage basin. Its water is extensively used for irrigation.

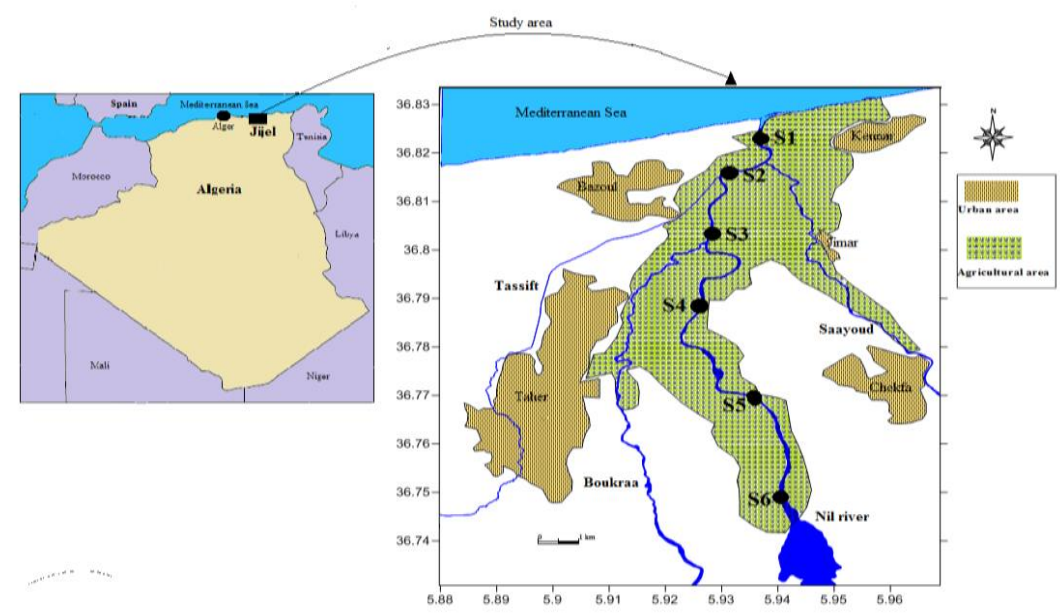

Figure 1. Sampling stations along the Nil river

\subsection{Ecology and morphology of P. australis (common reed)}

P. australis, known as common reed, is a kind of perennial grass that belongs to Poaceae family (Osma et al., 2015). It grows in marshes and swamps, along streams, lakes, ponds, ditches, and wet wastelands (Aksoy et al., 2005). It is a rhizomatous hemicryptophyte/geophyte whose stems grow to 2-6 m, and leaves are lanceolate, 20-50 cm long and $2-3 \mathrm{~cm}$ broad.P. australis can develop 6-10 m horizontal runners which put down roots at the nodes (Bonanno et al., 2010).

\subsection{Sample collection and analytical procedure}

\subsubsection{Sediment}

The sediment samples were collected from six different stations along the Nil river between February and June 2014 (Figure 1). At each site, 9 samples were taken using a clean plastic spoon at a depth of $20 \mathrm{~cm}$ from the surface. The collected sediment samples were packed and sealed in pre-washed polyethylene bags and transferred to the laboratory for pretreatment and analyses.

In the laboratory, the sediment samples were air-dried at room temperature, powdered, and sieved through a $2 \mathrm{~mm}$ and $63 \mu \mathrm{m}$ stainless steel sieve. The finest fraction (particles $<63 \mu \mathrm{m}$ ) was used to determine the heavy metals concentration and the $<2 \mathrm{~mm}$ fraction was used for the evaluation of sediment physicochemical parameters. Sediment's $\mathrm{pH}$ was measured with a $\mathrm{pH}$ meter in a suspension of $50 \mathrm{ml}$ de-ionized water and $20 \mathrm{~g}$ of sediment (1/2.5, sediment/ water ratio) after equilibration for $2 \mathrm{~h}$.

The grain size distribution in surface sediments was determined by pipette method.

The organic matter content of the sediment was evaluated by revised Walkley-Black titration method.

For the determination of total metals content, sediment samples were digested with aqua regia $\left(1 / 3 ; \mathrm{HNO}_{3} / \mathrm{HCl}\right)$; about $1 \mathrm{~g}$ of sediment was digested, with a mixture of $3 \mathrm{ml}$ $\mathrm{HCl}$ and $1 \mathrm{ml}$ of $\mathrm{HNO}_{3}$ at $120^{\circ} \mathrm{C}$.

\subsubsection{Plant}

Plant samples were collected from the same sites of sediment sampling. In the laboratory they were thoroughly rinsed with water to remove any sediment particles attached to the surface. The aboveground (leaves) and underground (roots) tissues were then separated, dried at $75^{\circ} \mathrm{C}$ to a constant weight, and ground into fine powder. 
The prepared samples were digested with a mixture of $3 \mathrm{ml}$ $\mathrm{HNO}_{3}, 3 \mathrm{ml}$ of $\mathrm{H}_{2} \mathrm{O}_{2}$ and $1 \mathrm{ml}$ of $\mathrm{H}_{2} \mathrm{SO}_{4}$ at $120{ }^{\circ} \mathrm{C}$ (Hoenig, 1990).

The concentrations of heavy metals ( $\mathrm{Pb}, \mathrm{Cd}, \mathrm{Zn}, \mathrm{Cr}$ and $\mathrm{Fe}$ ) in all samples (sediments and plant) were measured by Atomic Absorption Flame Emission Spectrophotometer (SHIMADZU AA6200).

\subsection{Data analysis}

\subsubsection{Sediment pollution indices}

The geo-accumulation index (I-geo) and enrichment factor were employed to assess the pollution of metals in the sediment of Nil river.

Geo-accumulation index is a quantitative measure of the degree of pollution in aquatic sediments (Rabee et al., 2011). It was determined by the following mathematical equation according to Müller (1969):

$$
\operatorname{lgeo}=\log _{2}(\mathrm{Cn} / 1.5 \times B n)
$$

Where, $\mathrm{Cn}$ is the measured concentration of the heavy metal ( $\mathrm{n}$ ) in the sediment and $\mathrm{Bn}$ is the geochemical background value in average shale of element $n$. The factor 1.5 is introduced to minimize the effect of possible variation in the background values that are due to lithological variations. The values of the average shale used in this work are those proposed by Turekian and Wedepohl (1961), (Table 2).

Müller (1981), proposed the following descriptive classes for increasing Igeo values:

Unpolluted (Class 0 , Igeo $\leq 0$ ), unpolluted to moderately polluted (Class $1,0<$ Igeo $\leq 1)$, moderately polluted (Class 2 , $1<$ lgeo $\leq 2$ ), moderately to strongly polluted (Class 3 , $2<$ lgeo $\leq 3$ ), strongly polluted (Class $4,3<$ lgeo $\leq 4$ ), strongly to very strongly polluted (Class $5,4<$ lgeo $\leq 5$ ) and very strongly polluted (Class 6, Igeo $>5$ ).

The enrichment factor (EF) was based on the standardization of a tested element against a reference one. The most common reference elements are $\mathrm{Sc}, \mathrm{Mn}, \mathrm{Ti}$, $\mathrm{Al}$ and $\mathrm{Fe}$ (Loska et al., 2004). In this study iron (Fe) is taken as a reference element. The enrichment factor (EF) is defined as follows:

$$
E F=\frac{(\mathrm{M} \text { sample } / \mathrm{Fe} \text { sample })}{(\mathrm{M} \text { average shale } / \mathrm{Fe} \text { average shale })}
$$

Where:

$M$ sample: concentration of the examined metal in the examined sediment

Fe sample: concentration of the reference metal in the examined sediment

$M$ average shale: concentration of the examined metal in the average shale

Fe average shale: concentration of the reference metal in the average shale (Çevik et al., 2009).

The EF values were interpreted as described by Chen et al., (2007). Where $E F<1$ indicates no enrichment, $E F<3$ is minor enrichment, $\mathrm{EF}=3-5$ is moderate enrichment, $\mathrm{EF}=5$ 10 is moderately severe enrichment, $E F=10-25$ is severe enrichment, $E F=25-50$ is very severe enrichment and $E F>50$ is extremely severe enrichment.

\subsubsection{Bioconcentration factors (BCF) and translocation} factors (TF)

The ability of plant to accumulate metals from their surrounding environments can be estimated using the bioconcentration factors $\mathrm{BCF}$, which is defined as the ratio of metal concentration in the roots to that in sediment ([Metal] Root/ [Metal] sediment) (Yoon et al., 2006).

The capacity of plant to translocate metals from the roots to the shoots is measured using the translocation factors TF, which is defined as the ratio of metal concentration in the shoots to the roots ([Metal] Shoot/ [Metal] Root) (Yoon et al., 2006).

\subsection{Statistical analysis}

One-way ANOVA was used to determine any significant difference in metal concentrations among different sampling stations. The correlation coefficients were used for estimating the correlation among metals and analyzed sediment parameters and among metal concentrations in sediment and plant organs. Values were reported as mean \pm standard deviation (SD). A significance level of 0.05 was used $(p<0.05)$.

\section{Results and discussion}

\subsection{General sediments characteristics}

The results of physicochemical parameters in surface sediments at different stations (S1-S6) are summarized in Table 1.

The results showed that the sediments of all the study stations were sandy to silty. The most widespread grain size in the sediments was the sand grains. Station 1, located at the vicinity of the mouths of Nil river, had the lowest percentage of sand, whereas station 6 had the highest sand.

As shown in Table 1, the $\mathrm{pH}$ of sediments from 6 stations was neutral to slightly alkaline with the minimum and maximum value; 7.39 and 8.47 respectively. According to Barakat et al., (2012), the neutral to slightly alkaline $\mathrm{pH}$, probably related to carbonate nature of the sediment and the organic matter accumulation in sediment, seems to be favorable for the immobilization of heavy metals.

The organic matter in the sediment ranged between $0.91 \%$ and $1.98 \%$. It was observed that the higher values were recorded at downstream stations (S1 and S2), while the lowest value was observed at station 6 . The relatively high content of organic Matter in downstream stations might be the result of the abundance of riparian vegetation and the high organic matter flux to sediments due to direct discharge of domestic wastewaters and rubbish in these stations. 
Table 1. Grain size and physicochemical characteristics of the sampled sediments at different stations

\begin{tabular}{cccccc}
\hline Stations & TOM (\%) & pH & Sand (\%) & Silt (\%) & Clay (\%) \\
\hline S1 & $1.98 \pm 0.01$ & $8.16 \pm 0.04$ & $70.82 \pm 1.60$ & $26.48 \pm 2.66$ & $2.69 \pm 0.86$ \\
\hline S2 & $1.97 \pm 0.01$ & $7.39 \pm 0.04$ & $71.91 \pm 1.30$ & $24.49 \pm 1.98$ & $3.59 \pm 0.94$ \\
\hline S3 & $1.80 \pm 0.04$ & $8.12 \pm 0.04$ & $79.33 \pm 1.33$ & $16.87 \pm 1.29$ & $3.79 \pm 0.34$ \\
\hline S4 & $1.65 \pm 0.02$ & $7.94 \pm 0.05$ & $81.70 \pm 0.94$ & $16.13 \pm 1.97$ & $2.80 \pm 0.88$ \\
\hline S5 & $1.41 \pm 0.02$ & $8.47 \pm 0.06$ & $82.89 \pm 1.26$ & $13.52 \pm 2.45$ & $3.43 \pm 0.43$ \\
\hline S6 & $0.91 \pm 0.02$ & $7.52 \pm 0.06$ & $84.59 \pm 1.53$ & $12.05 \pm 1.39$ & $3.36 \pm 0.92$ \\
\hline
\end{tabular}

\subsection{The concentration and distribution of heavy metals in sediments}

The results of the trace metal levels in the examined sediments are outlined in Table 2 . The mean heavy metal concentration $(\mu \mathrm{g} / \mathrm{g})$ ranged from $(65.13-85.15) \mathrm{Pb}$; $0.52-$ 1.57) Cd; (148.35-166.22) Zn; (47.55-62.17) $\mathrm{Cr}$ and (18164.54-19118.55) Fe. It was found that the order of abundance of these metals in sediments was as follows: Fe $>\mathrm{Zn}>\mathrm{Pb}>\mathrm{Cr}>\mathrm{Cd}$. Generally, most of the elements show a similar distribution patterns along the Nil river. Metals content was found decreasing with the increasing distance from the river mouth. According to the result of one-way ANOVA test, the concentration of all metals showed a significant difference among the stations $(p<0.05)$ (Table 2).

The lowest values of all metals were observed at station 6 . This can be explained by the fact that at this station there were less anthropogenic activities when compared to the other stations. However, the highest concentrations of metals were recorded at sampling stations which were adjacent to river mouths (station 1 and 2). This may be attributed to the important quantity of untreated wastewater, rubbish and effluents of agricultural land discharged into the river at these stations. Furthermore, the mean concentration of $\mathrm{Pb}, \mathrm{Cd}$ and $\mathrm{Zn}$ exceeded the background values (average shale) as proposed by Turekian and Wedepohl, (1961) (Table 2). Whereas, the average concentration of $\mathrm{Cr}$ and $\mathrm{Fe}$ was less than average shale. This indicates that metals, except $\mathrm{Cr}$ and $\mathrm{Fe}$, were not originated from natural sources and anthropogenic sources have a great contribution to the enrichment of these metals.

The assessment of heavy metals pollution was carried out using geoaccumulation index and enrichment factor.

Table 2. Heavy metal concentrations ( $\mu \mathrm{g} / \mathrm{g}$ ) in sediments of Nil river

\begin{tabular}{cccccc}
\hline Stations & Pb & Cd & Zn & Cr & Fe \\
\hline S1 & $85.15 \pm 4.78$ & $1.57 \pm 0.03$ & $166.22 \pm 4.22$ & $57.82 \pm 4.71$ & $19118.55 \pm 8.36$ \\
\hline S2 & $83.48 \pm 5.47$ & $1.40 \pm 0.02$ & $164.27 \pm 3.87$ & $62.17 \pm 4.17$ & $19017.49 \pm 4.15$ \\
\hline S3 & $80.08 \pm 5.10$ & $1.18 \pm 0.01$ & $161.73 \pm 4.25$ & $51.76 \pm 3.63$ & $18164.54 \pm 5.14$ \\
\hline S4 & $74.25 \pm 5.66$ & $1.33 \pm 0.56$ & $155.91 \pm 4.06$ & $54.61 \pm 4.65$ & $18540.55 \pm 1.42$ \\
\hline S5 & $68.01 \pm 5.34$ & $0.72 \pm 0.06$ & $151.27 \pm 6.38$ & $50.02 \pm 3.72$ & $18300.87 \pm 5.35$ \\
\hline S6 & $65.13 \pm 4.30$ & $0.52 \pm 0.04$ & $148.35 \pm 1.89$ & $47.55 \pm 2.73$ & $18771.03 \pm 4.86$ \\
*Aver. Shale & 20 & 0.3 & 95 & 90 & 47200 \\
\hline p & 0.0017 & 0.0008 & 0.0012 & 0.0078 & 0.00 \\
\hline
\end{tabular}

*Turekian and Wedenphol (1961), $p<0.05$

The results of geo-accumulation index reveal that sediments of Nil river are moderately polluted with $\mathrm{Pb}$, unpolluted to moderately polluted with $\mathrm{Zn}$ and unpolluted with $\mathrm{Cr}$ and $\mathrm{Fe}$. Igeo values of $\mathrm{Cd}$ indicate that sediments at S5 and S6 are unpolluted to moderately polluted, while the other stations are moderately polluted (Figure 2).

The values of enrichment factor indicate that all stations record moderate enrichment with $\mathrm{Zn}$ and minor enrichment with $\mathrm{Cr}$. Cd has the highest EF values and it is classified as severe enrichment in S1, S2, S3 and S4, moderately severe enrichment in S5 and moderate enrichment in $\mathrm{S6}$. For $\mathrm{Pb}$, the values of EF indicate that $\mathrm{S} 1$, S2 and S3 record severe enrichment while S4, S5 and S6 are moderately severe enrichment (Figure 3).

\subsubsection{Correlation analyses}

Correlation matrix for analyzed sediment parameters was used to investigate the factors controlling trace metals in sediments and to reveal if some of the metals were interrelated with each other. The results are presented in Table 3. These results showed that all metals have positive correlation with organic matter and silt and negative correlation with percentage of sand $(p<0,05)$. This comply with Halcrow et al., (1973) who mentioned that the heavy metals concentration increases with decrease in the particle size and increase of organic matter content. Sediments containing high levels of organic matter are likely to contain higher concentration of heavy metals as compared to sediments lacking organic matter (Ugwu et al., 2012). The fine-grained fraction $(\leq 63 \mu \mathrm{m})$ has a high specific surface area per unit quantity of material and, because of surface coatings of iron and manganese oxides and natural organic matter, it is more likely to adsorb organic and trace contaminations (Çevik et al., 2009; Naji et al., 2011). Furthermore, it was observed that the heavy metals were positively correlated with each other (except Fe) $(p<0.05)$, which may suggest a common pollution sources or a similar geochemical behavior for these metals (Ong et al., 2013). 
$\square \mathrm{pb} \square \mathrm{Cd} \square \mathrm{Zn} \square \mathrm{Cr} \square \mathrm{Fe}$

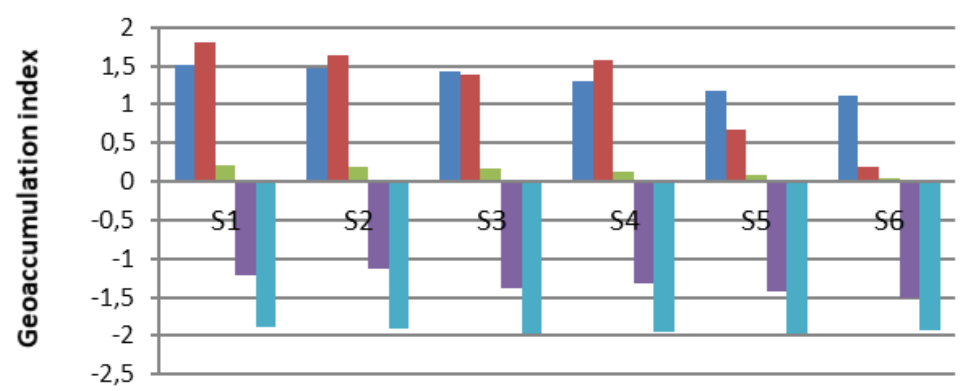

Stations

Figure 2. Geoaccumulation Index (I-geo) in surface sediments of Nil river

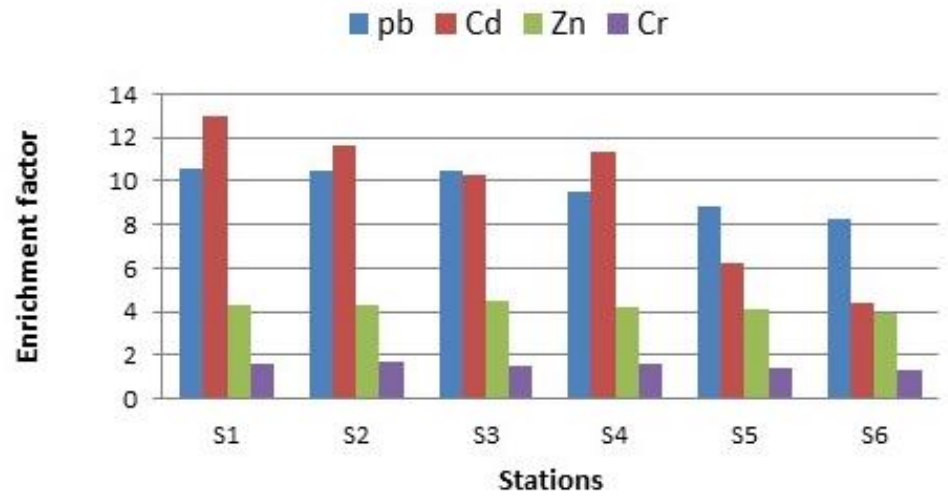

Figure 3. Enrichment factor (EF) in surface sediments of Nil river

Table 3. The correlation coefficients between sediment properties and heavy metals

\begin{tabular}{cccccc}
\hline & $\mathbf{P b}$ & $\mathbf{C d}$ & $\mathbf{Z n}$ & $\mathbf{C r}$ & $\mathbf{F e}$ \\
\hline $\mathbf{p H}$ & -0.05 & -0.03 & -0.02 & -0.30 & $-0.53^{*}$ \\
\hline TOM & $0.82^{*}$ & $0.84^{*}$ & $0.83^{*}$ & $0.71^{*}$ & 0.25 \\
\hline Sand & $-0.81^{*}$ & $-0.70^{*}$ & $-0.80^{*}$ & $-0.69^{*}$ & $-0.66^{*}$ \\
\hline Silt & $0.81^{*}$ & $0.71^{*}$ & $0.78^{*}$ & $0.68^{*}$ & $0.69^{*}$ \\
\hline Clay & -0.28 & -0.31 & -0.24 & -0.19 & -0.43 \\
\hline $\mathrm{Pb}$ & - & & & & \\
\hline $\mathrm{Cd}$ & $0.63^{*}$ & - & & & \\
\hline $\mathrm{Zn}$ & $0.69^{*}$ & $0.80^{*}$ & - & & \\
\hline $\mathrm{Cr}$ & $0.64^{*}$ & $0.75^{*}$ & $0.66^{*}$ & & - \\
\hline $\mathrm{Fe}$ & 0.37 & 0.37 & 0.36 & $0.52^{*}$ &
\end{tabular}

*Correlation is significant at the 0.05 level

\subsection{Heavy metals in plant}

The concentrations of $\mathrm{Pb}, \mathrm{Cd}, \mathrm{Zn}, \mathrm{Cr}$ and $\mathrm{Fe}$ in the organs of Phragmites australis (roots and leaves) are given in Table 4. The mean concentration values of these metals in both roots and leaves were observed in decreasing order as following: $\mathrm{Fe}>\mathrm{Zn}>\mathrm{Pb}>\mathrm{Cr}>\mathrm{Cd}$.

The results of this study showed that mean concentrations of all elements were less in the plants organs compared to the concentrations of the same elements in sediment. Positive correlation was found between the concentrations of metals in the sediment and plant organs (roots and leaves) (Table 5). This implies that the metal content in the plant was a result of the plant metal uptake from the sediments. Norozi Fard et al., (2016) reported that the soil fluid around the roots was the first source for the entry of heavy metals into the plant tissues and in total, the increased heavy metal concentration in the sediments increases the access of the plant. To this reason, the increase of metal amounts in surface layers of sediments mostly causes the increased accumulation of metals in the underground organs of the studied species.

Metals accumulated by P.australis were mostly distributed in root tissues, as shown by general TF values $<1$, except for $\mathrm{pb}$ in S1 and S2 (Table 6). These results are in accordance with the findings of other studies demonstrating that accumulated metals in the common reed are not distributed evenly. The underground organ shows a higher 
storage capacity than the above ground parts (Štrbac et al., 2014; Kucaj et al., 2015). Nouri et al., (2009) reported that the root tissues accumulate higher concentrations of metals than shoots, which indicated greater plant availability of the substrate metals, as well as interior limited mobility of the plant. According to Bonanno et al., (2010), the fact that roots showed high accumulation of elements may imply relevant availability in the sediment. Roots and rhizomes of $P$. australis can accumulate a great quantity of heavy metals because of the cortex parenchyma with large intercellular air spaces. Some plant species develop a strategy to avoid accumulation of toxic trace elements by storing them far away from the metabolically active structures, especially in the roots, so that even the elements absorbed in great quantities do not act as a phytotoxin to the plant (Mendonça et al., 2015).

Cadmium is a non-essential element for metabolic processes (Sasmaz et al., 2008), it is noted as one of the main eco-toxic metals that reveals catastrophic effects on the plants and entire physiological processes of living organisms (Norouznia et al., 2014). Kabata-Pendias and Pendias (2001) reported that $C d$ is easily absorbed by both root and leaf. According to the results of our study, $\mathrm{Cd}$ concentrations in the roots and leaves of $P$. australis were the lowest of all the investigated elements, due to low $\mathrm{Cd}$ content of the sediments. The mean $\mathrm{Cd}$ values detected $(0.08-0.32 \mu \mathrm{g} / \mathrm{g})$ were not in the phytotoxic range $(5-100$ $\mu \mathrm{g} / \mathrm{g}$ ) which is suggested by Chaney (1989).

Lead is not an essential element for plant growth but absorbed by the plant with other elements (Aksoy et al., 2005). It is particularly present in aquatic environments in areas with heavy traffic and neighboring cities (Kastratović et al., 2013).

In this present study, the mean concentrations of $\mathrm{Pb}$ in examinated tissues $(12.34-14.48 \mu \mathrm{g} / \mathrm{g})$ were below the phytotoxic range which is 30-300 $\mathrm{\mu g} / \mathrm{g}$ (Roos., 1994).

$\mathrm{Cr}$ is not essential for plants, it belongs to the group of elements that are harmful, and plants do not accumulate it in great amounts (Kucaj et al., 2015). Pais and Jones (2000) reported that $\mathrm{Cr}$ concentrations higher than $10 \mathrm{mg} / \mathrm{kg}$ had a phytotoxic effect on plants. In the current investigation, the mean values of $\mathrm{Cr}$ in the roots and leaves of $P$. australis (2.09-4.21 $\mu \mathrm{g} / \mathrm{g})$ do not exceed this limit.

Iron, directly or indirectly, is involved in many life processes of plants: Chlorophyll biosynthesis, photosynthesis, respiration, fixation of elemental nitrogen, nitrate and nitrite reduction, metabolism of carbohydrates and in different redox systems. However, high concentrations of this metal may result in oxidative stress for plant (Brankovic et al., 2011). Fe is the most abundant of all the investigated elements in $P$. australis, although its mean concentrations remain below the threshold of toxicity, ranging from 1000 to $3000 \mu \mathrm{g} / \mathrm{g}$ (Kabata-Pendias et al., 2001).

$\mathrm{Zn}$ is an essential and useful element for plants, mainly as a part of various metallo-enzymes (Kastratović et al., 2013). Among the examined elements, $\mathrm{Zn}$ was the most abundant element after Fe. Mean $\mathrm{Zn}$ concentrations ranged from $10.30 \mu \mathrm{g} / \mathrm{g}$ to $38.29 \mu \mathrm{g} / \mathrm{g}$ in examined tissues. These values were below the threshold of phytotoxicity which is 500$1500 \mu \mathrm{g} / \mathrm{g}$ as proposed by Chaney (1989).

To assess the ability of plant to accumulate and translocate heavy metals in their organs, Bioconcentration factors and translocation factors were calculated.

As shown in table 6 , the mean calculated BCF decreased in the following order: $\mathrm{Zn}>\mathrm{Cd}>\mathrm{Pb}>\mathrm{Cr}>\mathrm{Fe}$. Iron shows the lowest BCF although it is present in high concentrations in the sediment and in common reed. This result obtained confirms the earlier assumption that the metals in the sediment originating from the decomposition of rocks are usually connected in the form of chemical compounds that are not easily bioavailable to wildlife (Štrbac et al., 2014).

The values of translocation factors are shown in Table 6. Generally, the translocation factor (TF) showed low transport of elements from roots to shoots $(T F<1)$, indicating the inefficient translocating action from the root to the aerial plant parts (Al-Haidarey et al., 2010). In S1 and $\mathrm{S} 2$, the TF of $\mathrm{pb}$ was lower than one (concentration in the leaves is higher than in the roots), this may be explained by the fact that the leaves accumulate lead by deposition from the air (Štrbac et al., 2014), which is polluted by exhaust gases emitted from traffics (Brankovic et al., 2011).

Table 4. Heavy metal concentrations $(\mu \mathrm{g} / \mathrm{g})$ in roots and leaves of Phragmites australis

\begin{tabular}{cccccccc} 
& & S1 & S2 & S3 & S4 & S5 & S6 \\
\cline { 2 - 7 } Pb & $\mathbf{R}$ & $13.11 \pm 0.60$ & $13.09 \pm 0.55$ & $12.93 \pm 0.67$ & $12.91 \pm 0.50$ & $12.85 \pm 0.12$ & $12.78 \pm 0.23$ \\
& L & $14.48 \pm 0.43$ & $13.64 \pm 0.69$ & $12.84 \pm 0.28$ & $12.63 \pm 0.02$ & $12.63 \pm 0.03$ & $12.34 \pm 0.12$ \\
\hline Cd & R & $0.32 \pm 0.03$ & $0.27 \pm 0.02$ & $0.26 \pm 0.05$ & $0.23 \pm 0.04$ & $0.16 \pm 0.03$ & $0.11 \pm 0.02$ \\
& L & $0.19 \pm 0.09$ & $0.17 \pm 0.03$ & $0.16 \pm 0.09$ & $0.14 \pm 0.01$ & $0.10 \pm 0.08$ & $0.08 \pm 0.04$ \\
\hline Zn & $\mathbf{R}$ & $38.29 \pm 2.03$ & $37.15 \pm 2.15$ & $34.14 \pm 4.73$ & $29.13 \pm 1.87$ & $31.41 \pm 2.27$ & $28.93 \pm 1.37$ \\
& L & $28.41 \pm 7.44$ & $19.13 \pm 2.33$ & $21.99 \pm 1.16$ & $12.11 \pm 3.79$ & $13.46 \pm 2.13$ & $10.30 \pm 0.64$ \\
\hline Cr & R & $4.03 \pm 0.12$ & $4.13 \pm 0.10$ & $3.21 \pm 0.17$ & $3.59 \pm 0.02$ & $3.17 \pm 0.16$ & $3.06 \pm 0.35$ \\
& L & $2.48 \pm 0.11$ & $2.51 \pm 0.06$ & $2.36 \pm 0.14$ & $2.55 \pm 0.10$ & $2.25 \pm 0.08$ & $2.09 \pm 0.03$ \\
\hline Fe & R & $371.32 \pm 19.45$ & $358.38 \pm 25.84$ & $336.89 \pm 2.34$ & $349.80 \pm 10.72$ & $347.03 \pm 9.9$ & $352.08 \pm 20.37$ \\
& L & $304.05 \pm 5.56$ & $289.6 \pm 3.95$ & $281 . .74 \pm 1.53$ & $283.44 \pm 2.88$ & $280.28 \pm 3.75$ & $285.18 \pm 4.30$ \\
\hline
\end{tabular}

R: Roots, L: Leaves 
Table 5. Correlation coefficients of heavy metals among plant organs (roots and leaves) and sediments

\begin{tabular}{cccccccccc}
\hline & PbS & & CdS & & ZnS & CrS & FeS \\
\hline PbR & $0.62^{*}$ & $\mathrm{CdR}$ & $0.88^{*}$ & $\mathrm{ZnR}$ & $0.65^{*}$ & $\mathrm{CrR}$ & $0.80^{*}$ & FeR & $0.96^{*}$ \\
\hline $\mathrm{PbL}$ & $0.81^{*}$ & $\mathrm{CdL}$ & $0.49^{*}$ & $\mathrm{ZnL}$ & $0.76^{*}$ & $\mathrm{CrL}$ & $0.60^{*}$ & FeL & $0.77^{*}$ \\
\hline
\end{tabular}

S: Sediments, R: Roots, L: Leaves, *Correlation is significant at the 0.05 level.

Table 6. Bioconcentration factors (BCF) and translocation factors (TF) of metals in Phragmites australis

\begin{tabular}{ccccccccccc}
\hline & & \multicolumn{3}{c}{ BCF } & & & & & TF & Cr \\
\hline & $\mathbf{P b}$ & $\mathbf{C d}$ & $\mathbf{Z n}$ & $\mathbf{C r}$ & $\mathbf{F e}$ & $\mathbf{P b}$ & $\mathbf{C d}$ & $\mathbf{Z n}$ & $\mathbf{C r}$ \\
\hline S1 & 0.15 & 0.20 & 0.23 & 0.069 & 0.0194 & 1.10 & 0.59 & 0.74 & 0.61 & 0.818 \\
\hline S2 & 0.15 & 0.19 & 0.22 & 0.066 & 0.0188 & 1.04 & 0.62 & 0.51 & 0.60 & 0.808 \\
\hline S3 & 0.16 & 0.22 & 0.21 & 0.062 & 0.0185 & 0.99 & 0.61 & 0.64 & 0.73 & 0.836 \\
\hline S4 & 0.17 & 0.17 & 0.18 & 0.065 & 0.0188 & 0.97 & 0.60 & 0.41 & 0.71 & 0.810 \\
\hline S5 & 0.18 & 0.22 & 0.20 & 0.063 & 0.0189 & 0.98 & 0.62 & 0.42 & 0.70 & 0.807 \\
\hline S6 & 0.19 & 0.21 & 0.19 & 0.064 & 0.0187 & 0.96 & 0.72 & 0.35 & 0.68 & 0.809 \\
\hline
\end{tabular}

\section{Conclusion}

Given the results obtained in this study, it may be inferred that Nil river is facing serious environmental pollution, especially with $\mathrm{Pb}, \mathrm{Cd}$ and $\mathrm{Zn}$, which result from the continuous discharge of effluents in the river. Thus, the public health might be at highest risk since the water of river is extensively used for irrigation in the study area.

It is also noteworthy that the most severe pollution in river occurred at outfall where urban wastewater and effluents of agricultural land is discharged.

In the other hand, the results demonstrate that the concentration of heavy metals in the plants organs were less than those in the sediment and the metals accumulated by $P$. australis were mostly distributed in roots tissues. A positive association between the metal concentrations in $P$. australis organs and its environment was also found; this suggests that this plant can be used as biological indicator in biomonitoring studies.

\section{References}

Aksoy A., Demirezen D. and Duman F. (2005), Bioaccumulation, detection and analyses of heavy metal pollution in Sultan Marsh and its environment, Water, Air, and Soil Pollution, 164(1), 241-255.

Al-Haidarey M.J.S., Hassan F.M., Al-Kubaisey A.R.A and Douabul A.A.Z. (2010), The geoaccumulation index of some heavy metals in Al-Hawizeh Marsh, Iraq, E-Journal of Chemistry, 7(S1), 57-62.

Banerjee U. and Gupta S. (2012), Source and distribution of lead, cadmium, iron and manganese in the river Damodar near Asansol Industrial Area, West Bengal, India, International Journal of Environmental Science, 2(3), 15311542. doi:10.6088/ijes.00202030038.

Barakat A., El Baghdadi M., Rais J. and Nadem S. (2012), Assessment of heavy metal in surface sediments of Day River at Beni-Mellal region, Morocco, Research Journal of Environmental and Earth Sciences, 4(8), 797-806.

Bonanno G. and Giudice R.L. (2010), Heavy metal bioaccumulation by the organs of Phragmites australis (common reed) and their potential use as contamination indicators, Ecological Indicators, 10(3), 639-645. doi:10.1016/j.ecolind.2009.11.002.

Boudet L.C., Escalante A., Von Haeften G., Moreno V. and Gerpe M. (2011), Assessment of heavy metal accumulation in two aquatic macrophytes: a field study, Journal of the Brazilian Society of Ecotoxicology, 6(1), 57-64. doi: 10.5132/jbse.2011.01.009.

Brankovic S., Pavlovic-Muratspahic D., Topuzovic M., Glišic R., Bankovic D. and Stankovic M. (2011), Environmental study of some metals on several aquatic macrophytes, African Journal of Biotechnology, 10(56), 11956-11965. doi:10.5897/ajb10.2655.

Çevik F., Göks M.Z.L., Derici O.B. and Findik Ö. (2009), An assessment of metal pollution in surface sediments of Seyhan dam by using enrichment factor, geoaccumulation index and statistical analyses, Environnemental Monitoring and Assessment, 152(1), 309-317. doi 10.1007/s10661-0080317-3.

Chaney R.L. (1989), Toxic element accumulation in soils and crops: protecting soil fertility and agricultural food chains, In: Bar-Yosef B, Barrow NJ, Goldshmid J (ed) Inorganic Contaminants in the Vadose Zone, Springer-Verlag Berlin Heidelberg.

Chen C.W., Kao C.M., Chen C.F. and Dong C.D. (2007), Distribution and accumulation of heavy metals in the sediments of Kaohsiung Harbor, Taiwan, Chemosphere, 66(8),

1431-1440. doi:10.1016/j.chemosphere.2006.09.030.

Halcrow W., Mackay D.W. and Thornton L. (1973), The distribution of trace metals and fauna in the Firth of Clyde in relation to the disposal of sludge, Journal of the Marine Biological Association UK, 53(3), 721-739.

Hoenig M. (1990), Spectrométrie d'absorbtion atomique électrothermique: Contribution à l'établissement d'une méthodologie rationnelle pour la détermination des éléments traces dans les milieux naturels, doctoral thesis, University of Science and Technology, Lille Flandres Artois.

Kabata-Penias A.d. and Pendias H. (2001), Trace Elements in Soils and plants, CRC Press, Boca Raton London, D.C.

Kastratović V., Krivokapić S., Đurović D. and Blagojević N. (2013), Seasonal changes in metal accumulation and distribution in the organs of Phragmites australis (common reed) from Lake Skadar, Montenegro, Journal of the Serbian 
Chemical Society, 78(8), 1241-1258. doi: 10.2298/JSC121026153K.

Kucaj E. and Abazi U. (2015), Assessment of heavy metals in sediments and Phragmites Australis in Tirana river, Albania, European Journal of Physical and Agricultural Sciences, 3(2), 54-61.

Kuntal S. and Reddy M.N. (2014), Accumulation of heavy metals by some aquatic macrophytes in estuarine zone of River Tapi, Surat, Gujarat, India, International Journal of Innovative Research in Science, Engineering and Technology, 3(4), 11125-11134.

Loska K., Wiechuła D. and Korus I. (2004), Metal contamination of farming soils affected by industry, Environment International, 30(2), 159-165. doi:10.1016/S01604120(03)00157-0.

Mendonça T.G. and Figueiredo B.R. (2015), Metal accumulation by Typha dominguensis Pers. From a hygrophilous forest fragment in Brazil, Geochimica Brasiliensis, 29(2), 58-69.

Müller G. (1981), The heavy metal content of the sediments of the Neckar and its tributaries: an inventory, Chem Zeitung, 105, 157-164.

Muller G. (1969), Index of geoaccumulation in sediments of the Rhine River, Journal of Geology, 2(3), 108-118.

Milenkovic N., Damjanovic M. and Ristic M. (2005), Study of Heavy Metal Pollution in Sediments from the Iron Gate (Danuae River), Serbia and Montenegro, Polish Journal of Environmental Studies, 14(6), 781-787.

Naji A. and Ismail A. (2011), Assessment of metals contamination in Klang River surface sediments by using different indexes, Environment Asia, 4(1), 30-38.

Norouznia H. and Hamidian A.H. (2014), Phytoremediation efficiency of pondweed (Potamogeton crispus) in removing heavy metals $(\mathrm{Cu}, \mathrm{Cr}, \mathrm{Pb}, \mathrm{As}$ and $\mathrm{Cd})$ from water of Anzali wetland, International Journal of Aquatic Biology, 2(4), 206214.

Norozi Fard P., Mortazavi S. and leldromi A. (2016), Common Reed (Phragmites australis) as a Bio Refining and Monitoring Plant of Pollution Resulting from Heavy Metals (Case Study: Dez River, Dezful, Iran), Journal of Rangeland Science, 6(1), 10-23.

Nouri J., Khorasani N., Lorestani B., Karami M., Hassani AH. and Yousefi N. (2009), Accumulation of heavy metals in soil and uptake by plant species with phytoremediation potential, Environmental Earth Sciences, 59(2), 315-323. doi 10.1007/s12665-009-0028-2.

Ong M.C., Menier D., Shazili N.A.M. and Kamaruzzaman B.Y. (2013), Geochemical characteristics of heavy metals concentration in sediments of Quiberon Bay Waters, South Brittany, France, Oriental Journal of Chemistry, 29(1), 3945.

Osma E., Ihlan V. and Yalcin I.E. (2015), Uptake of selected heavy metals and their effects on some physiologic parameters and mineral nutrition in Phragmites australis in Karasu river -Turkey, Global Nest Journal, 17(3), 555-564.

Pais I. and Jones J.B. (1997), The Handbook of Trace Elements, St Luice Press, Boca Raton, Florida.

Rabee A.M., Al-Fatlawy Y.F., Abdown A.N. and Nameer M. (2011), Using Pollution Load Index (PLI) and geoaccumulation index (I-Geo) for the assessment of heavy metals pollution in Tigris river sediment in Baghdad Region, Journal of Al-Nahrain University, 14(4), 108-114.
Roos M.S. (1994), Sources and forms of potentially toxic metals in soil-plant systems, In: Ross MS (ed) Toxic Metals in SoilPlant System. John Wiley and Sons, Chichester, New York pp 3-25.

Sasmaz A., Obek E. and Hasar H. (2008), The accumulation of heavy metals in Typha latifolia L. grown in a stream carrying secondary effluent, Ecological engineering, 33(3), 278-284.

Štrbac S., Šajnović A., Kašanin Grubin M., Vasić N., Dojčinović B., Simonović P. and Jovančićević B. (2014), Metals in sediment and Phragmites Australis (common reed) from Tisza river, Serbia, Applied Ecology and Environmental Research, 12(1), 105-122.

Turekian K.K. and Wedepohl K.H. (1961), Distribution of the elements in some major units of the Earth's Crust, Geological Society of America Bulletin, 72, 175-192.

Ugwu A.I., Wakawa R.J., La'ah E. and Olotu A. (2012), Spatial Distribution of Heavy Metals in River Usuma Sediments and Study of Factors Impacting the Concentration, International Journal of Research and Reviews in Applied Sciences, 12(2), $294-303$.

Yoon J., Cao X., Zhou Q. and Ma L.Q. (2006), Accumulation of $\mathrm{Pb}, \mathrm{Cu}$, and $\mathrm{Zn}$ in native plants growing on a contaminated Florida site, Science of the Total Environment, 368(2), 456464. doi:10.1016/j.scitotenv.2006.01.016. 